\title{
Light microscopy of the endometrium of the dusky leaf-monkey (Presbytis obscura)
}

\author{
G. J. Burton \\ Department of Anatomy, University of Cambridge, Cambridge CB2 3DY, U.K.
}

\begin{abstract}
Summary. Specimens of this langur species were available from juvenile, adult and lactating animals. The endometrial sections of non-pregnant adults were dated from the ovarian appearances. During the cycle the endometrium underwent changes similar to those described for women, baboons and macaques, except that stromal oedema was pronounced and diffuse in the langur, occurring before ovulation and throughout the secretory phase.
\end{abstract}

\section{Introduction}

Members of the genus Presbytis are leaf-eating monkeys of the family Cercopithecidae and sub-family Colobinae. Commonly known as langurs, they are revered by many Indians as the monkey deity Hanuman (Blandford, 1888; Jay, 1965). The genus is found throughout India, Pakistan and South-East Asia although Presbytis obscura is limited to Southern Burma, Thailand and Malaya (Napier \& Napier, 1967; Roonwal \& Mohnot, 1977). Whilst there are many reports of dietary and social behaviour (see Napier \& Napier, 1967, for review) little is known about reproduction in these monkeys.

Menstrual cycles first occur when the female langur is between 3 and 4 years old (Hill, 1936; Jay, 1965). Whilst the first few cycles are irregular, in the adult menstruation takes place every 3-4 weeks and lasts about 2-4 days (Hill, 1936; Asdell, 1965; Badham, 1967). The female appears to be receptive for only 5-7 days midway through the cycle and there are no discernible changes in the external genitalia (Jay, 1965). Ayer (1948) described the gross morphology of the non-pregnant uterus of a sub-adult grey langur, Presbytis entellus, and Heape (1894) described 8 stages of menstruation in the same species. Zuckerman (1931) commented on these findings and the relationship between the ovarian and uterine cycles. There are no accounts of the menstrual cycle of the dusky leaf-monkey, Presbytis obscura.

The present paper describes the histological appearance of the uteri of pre-pubertal, adult and lactating dusky leaf-monkeys.

\section{Materials and Methods}

The material on which this report is based forms part of a collection of Presbytis obscura material presented to the Cambridge University Department of Anatomy by Lord Cranbrook. The collection was made in West Malaysia during 1967 and early 1968 from 44 female monkeys, shot by the Malaysian authorities as part of a pest control operation. At post-mortem examination 4 were noted to be juveniles, 11 were found to be in various stages of pregnancy and 5 were lactating. After weighing the organs, the uteri and ovaries were fixed in $10 \%$ formalin, dehydrated in ethanol and embedded in paraffin wax. Serial sections of the ovaries and 
representative sections of the uteri were cut at $8 \mu \mathrm{m}$ and stained with haematoxylin and eosin for histological examination. The sections were stored and presented to this Department in 1978. Both ovaries were available from all 44 animals but there were only 3, 20, 2 and 5 uteri from the juvenile, adult non-pregnant, pregnant and lactating groups respectively.

Generally the fixation of the specimens had been good and in most cases accurate measurements could be made using an eyepiece graticule. For each measurement 10 readings were taken from different sections of the same specimen and the mean value was recorded.

Accurate dating of the adult endometrium was impossible from the fixed tissue alone, but on the basis of the ovarian histology the specimens could be assigned to the menstruating, early proliferative, late proliferative, early secretory and late secretory phases of the menstrual cycle. Vaginal specimens were not available.

\section{Results}

\section{General}

The mean uterine weight for the juvenile and adult (non-pregnant and non-lactating) monkeys was $0.75 \pm 0.28 \mathrm{~g}(n=4)$ and $4.50 \pm 0.49 \mathrm{~g}(n=19)$ respectively. Whilst no strict correlations could be determined, the uterine weight and its relative contribution to the total body weight appeared highest during the late proliferative and secretory phases of the menstrual cycle (Table 2).

The myometrium was relatively unchanged throughout the cycle and had a mean thickness of $2.3 \mathrm{~mm}$ in the adult. It was composed of alternating bundles of smooth muscle fibres arranged in longitudinal, circular and oblique array. The peritoneal surface was covered by a simple squamous epithelium.

\section{Pre-pubertal monkeys}

The post-mortem diagnosis was confirmed by examination of the ovaries. The absence of developing follicles and any form of corpus luteum or corpus albicans indicated that cyclic activity had not started.

Table 1. Measurements (means of 10 values) on individual prepubertal dusky leaf-monkeys

\begin{tabular}{ccccccc}
\hline & & & \multicolumn{3}{c}{ Thickness } \\
\cline { 5 - 7 } Monkey & $\begin{array}{c}\text { Body wt } \\
(\mathrm{kg})\end{array}$ & $\begin{array}{c}\text { Uterine wt } \\
(\mathrm{g})\end{array}$ & $\begin{array}{c}\text { Uterine wt/body } \\
\text { wt } \times 1000\end{array}$ & $\begin{array}{c}\text { Myometrium } \\
(\mathrm{mm})\end{array}$ & $\begin{array}{c}\text { Endometrium } \\
(\mathrm{mm})\end{array}$ & $\begin{array}{c}\text { Luminal epi- } \\
\text { thelium }(\mu \mathrm{m})\end{array}$ \\
\hline 1 & 2.3 & 0.5 & 0.2 & 0.80 & 0.10 & 10.8 \\
2 & 3.8 & 0.5 & 0.1 & 0.78 & 0.16 & 12.9 \\
3 & 4.0 & 1.6 & 0.4 & 1.12 & 0.14 & 13.4 \\
\hline
\end{tabular}

The uteri were small and lined by a thin layer of endometrium (Table 1). The uterine epithelium consisted of a single layer of columnar cells lying on a well developed basement membrane. The cell nuclei were 9-10 $\mu \mathrm{m}$ diameter (PI. 1, Fig. 1). Stellate cells with ovoid nuclei, 5-6 $\mu \mathrm{m}$ diameter, formed a loose endometrial stroma which had an indistinct boundary with the myometrium. Blood vessels were prominent in both layers. The uterine glands had relatively wide necks and penetrated deep into the myometrium. Lined by tall columnar cells with basally situated nuclei they showed no evidence of secretory activity. 


\section{Adult monkeys}

Menstruating. During menstruation the endometrium was shed to about one-quarter of the thickness attained at the end of the secretory phase. Throughout the loose endometrial stroma were large collections of free erythrocytes. Leucocytes intermingled with the degenerated stromal cells and the whole appeared to be shed in an irregular manner.

Early proliferative phase. Small developing ovarian follicles were associated with a thin, flat endometrium (Table 2), the lining of which varied from a low cuboidal to a columnar epithelium. Mitotic figures were common in the uterine epithelium and the densely packed stroma. The endometrial cells had irregular shaped nuclei with a mean diameter of $5.2 \mu \mathrm{m}$. Free erythrocytes were occasionally seen in the superficial parts of the stroma. The scanty uterine glands were lined by a tall columnar epithelium which contrasted markedly with the uterine lining (Pl. 1, Fig. 2). The nuclei of the glandular cells were situated basally and there was no evidence of secretory activity; menstrual debris alone filled the gland lumina.

Table 2. Measurements (means of 10 values) on adult dusky leaf-monkeys at various stages of the menstrual cycle

\begin{tabular}{|c|c|c|c|c|c|c|c|}
\hline \multirow[b]{2}{*}{ Monkey } & \multirow[b]{2}{*}{$\begin{array}{l}\text { Body } \\
\text { wt } \\
(\mathrm{kg})\end{array}$} & \multirow[b]{2}{*}{$\begin{array}{l}\text { Uterine } \\
\text { wt } \\
(\mathrm{g})\end{array}$} & \multirow[b]{2}{*}{$\begin{array}{c}\text { Uterine } \\
\text { wt } / \text { body } \\
\text { wt } \times 1000\end{array}$} & \multicolumn{3}{|c|}{ Thickness } & \multirow[b]{2}{*}{$\begin{array}{c}\text { No. of } \\
\text { stromal cell } \\
\text { nuclei } / 100 \mu \mathrm{m}^{2}\end{array}$} \\
\hline & & & & $\begin{array}{l}\text { Myometrium } \\
(\mathrm{mm})\end{array}$ & $\begin{array}{l}\text { Endometrium } \\
(\mathrm{mm})\end{array}$ & $\begin{array}{l}\text { Luminal epi- } \\
\text { thelium }(\mu \mathrm{m})\end{array}$ & \\
\hline \multicolumn{8}{|c|}{ Early proliferative } \\
\hline 4 & 6.7 & 2.5 & 0.4 & 1.84 & 0.22 & $14 \cdot 3$ & 12 \\
\hline 5 & 6.9 & 3.0 & 0.4 & $2 \cdot 20$ & 0.19 & 13.9 & 13 \\
\hline 6 & 6.7 & $6 \cdot 5$ & 1.0 & $2 \cdot 10$ & 0.49 & $8 \cdot 5$ & 7 \\
\hline 7 & $6 \cdot 3$ & $3 \cdot 2$ & 0.5 & 2.20 & 0.28 & $15 \cdot 1$ & 9 \\
\hline 8 & $5 \cdot 8$ & $4 \cdot 1$ & 0.7 & 1.94 & 0.26 & 9.9 & 12 \\
\hline 9 & - & $2 \cdot 8$ & - & $2 \cdot 30$ & 0.42 & $12 \cdot 9$ & 12 \\
\hline 10 & $7 \cdot 1$ & 1.9 & 0.3 & 1.62 & 0.34 & 10.9 & 10 \\
\hline 11 & 6.5 & 3.5 & 0.5 & $2 \cdot 20$ & 0.32 & 6.5 & 5 \\
\hline \multicolumn{8}{|c|}{ Mid-proliferative } \\
\hline 12 & $6 \cdot 3$ & 2.8 & 0.4 & 1.76 & 0.68 & $14 \cdot 0$ & 8 \\
\hline 13 & 4.9 & 3.5 & 0.7 & 1.78 & 0.26 & $14 \cdot 0$ & 11 \\
\hline 14 & - & 3.5 & - & 1.84 & 0.44 & $14 \cdot 0$ & 5 \\
\hline 15 & $6 \cdot 2$ & $3 \cdot 2$ & 0.5 & $2 \cdot 15$ & 0.45 & $11 \cdot 8$ & 8 \\
\hline \multicolumn{8}{|c|}{ Late proliferative } \\
\hline 16 & $6 \cdot 3$ & 8.0 & $1 \cdot 3$ & $3 \cdot 78$ & $3 \cdot 15$ & $16 \cdot 6$ & 2 \\
\hline 17 & 4.9 & $5 \cdot 0$ & 1.0 & $1 \cdot 50$ & 1.0 & $15 \cdot 8$ & 3 \\
\hline \multicolumn{8}{|c|}{ Early secretory } \\
\hline 18 & $6 \cdot 3$ & $8 \cdot 3$ & $1 \cdot 3$ & $2 \cdot 20$ & $2 \cdot 60$ & $26 \cdot 1$ & 3 \\
\hline 19 & 6.6 & $6 \cdot 0$ & 0.9 & 1.50 & 2.40 & $24 \cdot 8$ & 3 \\
\hline 20 & $6 \cdot 2$ & 3.8 & 0.6 & $2 \cdot 20$ & Ep lost & Ep lost & 3 \\
\hline \multicolumn{8}{|c|}{ Late secretory } \\
\hline 21 & 7.8 & 9.5 & 1.2 & 2.90 & $2 \cdot 10$ & $16 \cdot 1$ & 2 \\
\hline 22 & - & 4.4 & - & 1.73 & 0.74 & $15 \cdot 2$ & 5 \\
\hline
\end{tabular}

Ep, epithelium.

Mid-proliferative phase. The endometrium was thicker and lined by a well developed columnar epithelium (Table 2). The stroma was less dense than in the previous phase and neither free erythrocytes nor leucocytes were seen. The uterine glands were more numerous and straight, and their columnar lining exhibited many mitotic figures.

Late proliferative phase. Large Graafian follicles were associated with a thick endometrium lined by a tall columnar epithelium showing pseudostratification (Pl. 1, Fig. 3). The stromal cells were very loosely packed and their round nuclei were up to $7.2 \mu \mathrm{m}$ in diameter (PI. 1, Fig. 4). 
Capillaries were conspicuous within the stroma, particularly near the luminal surface. The uterine glands appeared more tortuous at their bases and mitotic figures were abundant. The glandular lumina were empty.

Early secretory phase. After ovulation, whilst the corpus luteum still had a core of blood and fibrin, the endometrium was lined by a columnar epithelium taller than at any other phase of the cycle (Table 2). Within the loosely packed stroma the uterine glands had a classical saw-toothed appearance (Pl. 2, Fig. 5). Numerous clear vacuoles filled the basal portions of the glandular epithelial cells but there was little evidence of active secretion.

Late secretory phase. Whilst the endometrium remained thick the uterine epithelium was lower than in the previous phase of the cycle (Table 2). The luminal and glandular epithelia showed signs of active secretion; the cells possessing numerous apical projections which appeared to be pinched off and could be seen free within the lumen of the glands (Pl. 2, Fig. 6). Mitotic figures were rare in both epithelia and the stroma. Large collections of free erythrocytes were visible within the endometrium but although the endothelial cells appeared prominent no gross disruption of the vessel walls could be detected.

Lactating. During lactation the endometrium remained low and was covered by a columnar epithelium 10-12 $\mu \mathrm{m}$ thick. Occasional mitotic figures were seen in the epithelium and the densely packed stroma. The uterine glands were scanty and there was no secretory activity of the columnar epithelium. The overall appearance was very similar to that of the early proliferative phase.

\section{Discussion}

The family Cercopithecidae contains two sub-families; the Colobinae, which includes the langurs, proboscis and colobus monkeys, and the Cercopithecinae, which includes the vervets, talapoins, baboons and macaques. Of these, reproduction has been most extensively investigated in the baboons and macaques.

In duration the menstrual cycle of the langur would appear more comparable with the 27-28-day cycle of the macaque (Corner, 1923; Hartman, 1932), than with the 32-33-day cycle of the baboon (Hendrickx \& Kraemer, 1971; Dollar, Hand, Beck \& Boots, 1979).

The gross morphology of the uterus is similar in the three genera, the uterus being simple with no separation into horns. However, the macaque is distinctive in having a particularly tortuous cervical canal (Clark \& Corner, 1935; Ayer, 1948; Hendrickx \& Kraemer, 1971).

The study confirms that with few exceptions the histological changes observed during the menstrual cycle of the dusky leaf-monkey are similar to those previously reported in the baboon and macaque (Zuckerman \& Parkes, 1932; Bartlemaz, Corner \& Hartman, 1951; MacLennan \& Wynn, 1971; Kraemer, Maqueo, Hendrickx \& Vera Cruz, 1977). The most remarkable difference is the early appearance, before ovulation, of pronounced and diffuse stromal oedema in the langur. Oedema occurs to only a moderate extent in the macaque and is virtually absent in the baboon. In women it occurs slightly in the mid-proliferative phase but predominantly in the late secretory phase (Noyes, Hertig \& Rock, 1950). The significance of this stromal oedema remains uncertain.

The lack of genital swelling at the time of ovulation makes dating the endometrium difficult in this species and no data concerning other possible indicators of ovulation, such as changes in basal body temperature or vaginal cytology, are available. However, although the sections could not be dated with sufficient accuracy to carry out detailed comparisons of growth rates, this study does show that, with the exception of stromal oedema, the criteria described by Noyes et al. (1950) for dating the human endometrium are also applicable to the langur. 

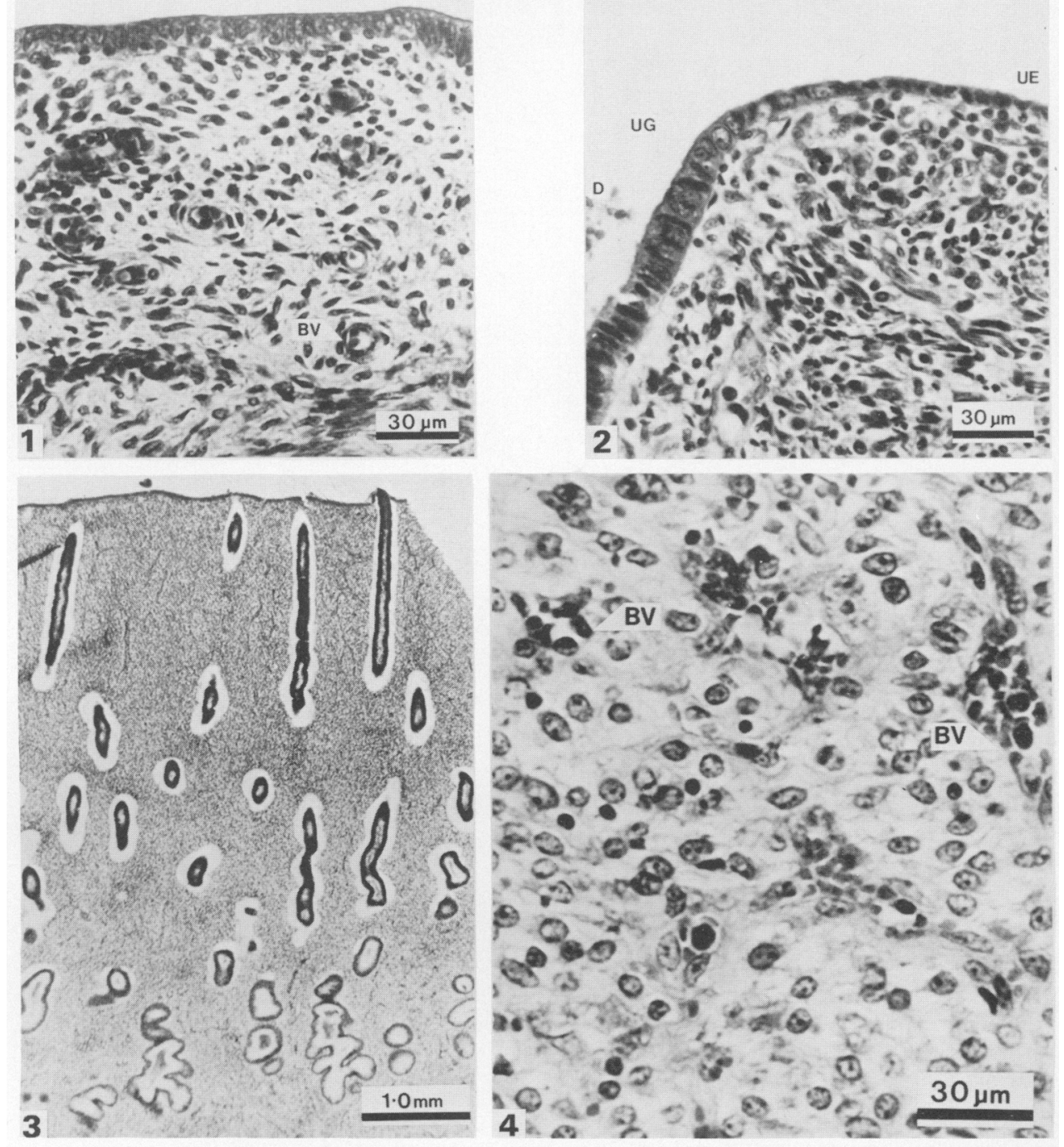

Fig. 1. High-power photomicrograph of the prepubertal uterus (Monkey 1) showing columnar epithelium lining a loosely packed endometrial stroma in which blood vessles (BV) are frequently seen.

Fig. 2. High-power photomicrograph of the uterus in the early proliferative phase (Monkey 11) showing the marked contrast between the columnar epithelium of a uterine gland (UG) and the cuboidal uterine epithelium (UE). D, menstrual debris.

Fig. 3. The thick endometrium in the late proliferative phase (Monkey 16) contains numerous uterine glands with long, straight necks. The ovaries of this monkey contained an unruptured follicle $6 \mathrm{~mm}$ in diameter.

Fig. 4. High-power photomicrograph of the same specimen as Fig. 3. The endometrial stroma immediately beneath the uterine epithelium is markedly oedematous at this stage of the cycle and contains numerous blood vessels (BV).

(Facing p. 110) 


\section{PLATE 2}
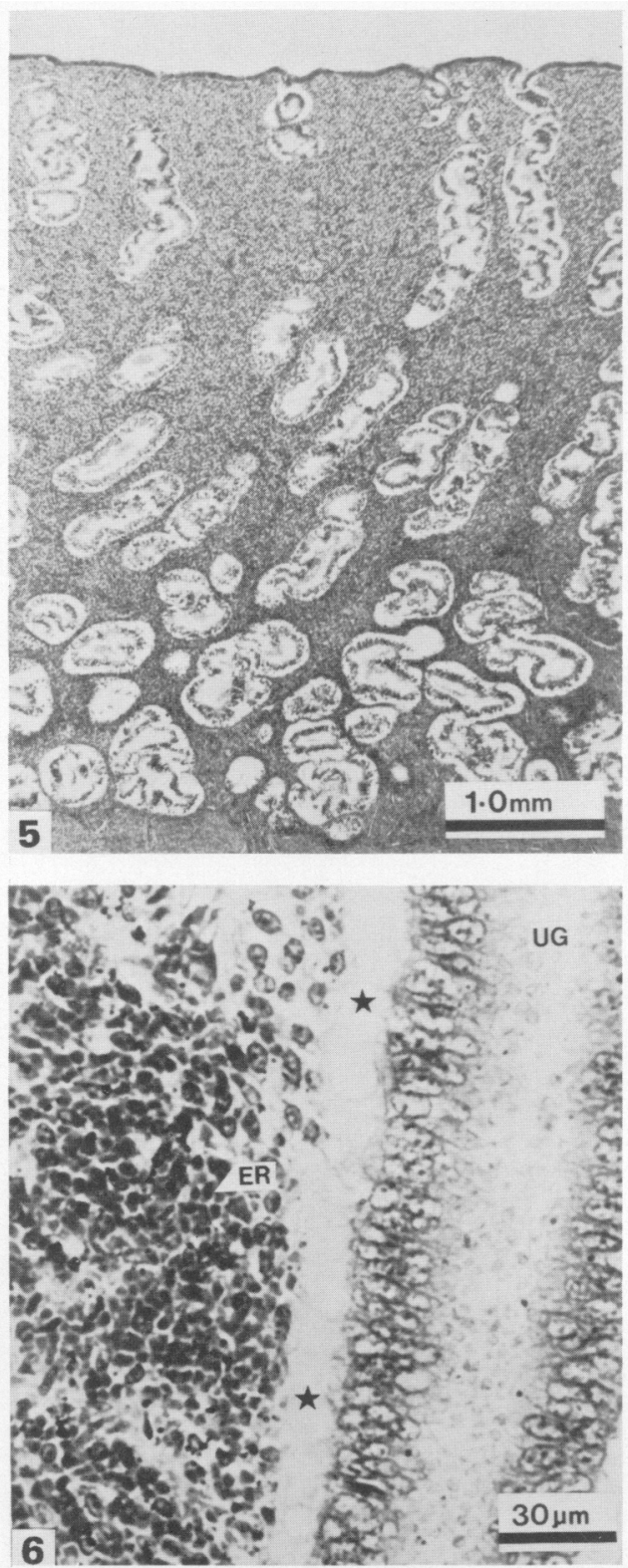

Fig. 5. In the early secretory phase (Monkey 18), the uterine glands are tortuous but secretory activity has not yet begun.

Fig. 6. High-power photomicrograph of a uterus in the late secretory phase (Monkey 21). Numerous free erythrocytes (ER) are seen within the endometrial stroma whilst the epithelium of the uterine gland (UG) shows pronounced secretory activity. The cells possess apical projections which appear to be pinched off and are seen free within the lumen of the gland. The space $(*)$ is a fixation artefact. 
The Cambridge University Department of Anatomy thanks Lord Cranbrook for the material presented. I also thank Mr J. F. Crane and Mr C. F. Burton for their help with the photomicrographs.

Thanks are also given to the staff of the Perak State Game Department and of the Department of Zoology, University of Malaya, in particular to Encik Mohamed Khan bin Momin Khan and Encik David Labang, for their help in the collection and preparation of the material.

\section{References}

Asdell, S.A. (1965) Patterns of Mammalian Reproduction, 2nd edn. Constable, London.

Ayer, A.A. (1948) The Anatomy of Semnopithecus entellus. The Indian Publishing House Limited, Madras.

Badham, M. (1967) A note on breeding the Spectacled leaf monkey (Presbytis obscura) at Twycross Zoo. Int. Zoo Ybk 7, 89.

Bartlemaz, G.W., Corner, G.W. \& Hartman, C.G. (1951) Cyclic changes in the endometrium of the rhesus monkey (Macaca mulatta). Contr. Embryol. Carneg. Instn 34, 101-144.

Blandford, W.T. (1888) The Fauna of British India. Mammalia. Taylor and Francis, London.

Clark, O.M. \& Corner, G.W. (1935) The cervix uteri of the rhesus monkey. Anat. Rec. 63, 247-252.

Corner, G.W. (1923) Ovulation and menstruation in Macacus Rhesus. Contr. Embryol. Carneg. Instn 15, 73-101.

Dollar, J.R., Hand, G.S., Beck, L.R. \& Boots, L.R. (1979) The baboon as a primate model for the study of endometrium. Am. J. Obstet. Gynec. 134, 305309.

Hartman, C.G. (1932) Studies in the reproduction of the monkey Macacus (Pithecus) rhesus, with special reference to menstruation and pregnancy. Contr. Embryol. Carneg. Instn 23, 1-162.

Heape, W. (1894) The menstruation of Semnopithecus entellus. Phil. Trans. R. Soc. B 411-471.

Hendrickx, A.G. \& Kraemer, D.C. (1971) Reproduction. In Embryology of the Baboon, pp. 1-30. Ed. A. G. Hendrickx. Chicago University Press, Chicago.
Hill, W.C.O. (1936) On a hybrid leaf-monkey; with remarks on the breeding of leaf-monkeys in general. Ceylon J. Sci. (B) 20, 135-148.

Jay, P. (1965) The common langur of North India. In Primate Behaviour, pp. 197-249. Ed. I. De Vore. Holt, Rinehart and Winston, New York.

Kraemer, D.C., Maqueo, M., Hendrickx, A.G. \& Vera Cruz, N.C. (1977) Histology of the baboon endometrium during the menstrual cycle and pregnancy. Fert. Steril. 28, 482-487.

MacLennan, A.H. \& Wynn, R.M. (1971) Menstrual cycle of the baboon $\mathbf{I}$. Clinical features, vaginal cytology and endometrial histology. Obstet. Gynec., N.Y. 38, 350-374.

Napier, J.R. \& Napier, P.M. (1967) A Handbook of Living Primates. Academic Press, London.

Noyes, R.W., Hertig, A.T. \& Rock, J. (1950) Dating the endometrial biopsy. Fert. Steril. 1, 3-25.

Roonwal, M.L. \& Mohnot, S.M. (1977) Primates of South Asia. Harvard University Press, Cambridge, Massachusetts.

Zuckerman, S. (1931) The menstrual cycle of the Primates. Part 3. The alleged breeding-season of primates, with special reference to the Chacma baboon (Papio porcarius). Proc. zool. Soc. Lond. 325-343.

Zuckerman, S. \& Parkes, A.S. (1932) The menstrual cycle of the Primates. Part V. The cycle of the Baboon. Proc. zool. Soc. Lond. 139-191.

Received 30 September 1979 